\title{
Publisher Correction: Necroptosis mediates myofibre death in dystrophin-deficient mice
}

Jennifer E. Morgan ${ }^{1}$, Alexandre Prola (10 ${ }^{2}$, Virginie Mariot ${ }^{3}$, Veronica Pini ${ }^{1}$, Jinhong Meng ${ }^{1}$, Christophe Hourde ${ }^{4}$, Julie Dumonceaux ${ }^{3}$, Francesco Conti (1D) ${ }^{1}$, Frederic Relaix 2,5, Francois-Jerôme Authier ${ }^{2,5}$, Laurent Tiret (D) ${ }^{2}$, Francesco Muntoni ${ }^{1} \&$ Maximilien Bencze (iD ${ }^{1,2}$

Correction to: Nature Communications https://doi.org/10.1038/s41467-018-06057-9; published online 07 September 2018

The original version of this article contained an error in Fig. 3. In panel c, the labels 'mdx' and 'mdx Ripk3-/- were inadvertently inverted. This has now been corrected in the PDF and HTML versions of the article.

Published online: 02 October 2018

\begin{abstract}
(c) Open Access This article is licensed under a Creative Commons Attribution 4.0 International License, which permits use, sharing, adaptation, distribution and reproduction in any medium or format, as long as you give appropriate credit to the original author(s) and the source, provide a link to the Creative Commons license, and indicate if changes were made. The images or other third party material in this article are included in the article's Creative Commons license, unless indicated otherwise in a credit line to the material. If material is not included in the article's Creative Commons license and your intended use is not permitted by statutory regulation or exceeds the permitted use, you will need to obtain permission directly from the copyright holder. To view a copy of this license, visit http://creativecommons.org/licenses/by/4.0/.
\end{abstract}

(C) The Author(s) 2018

\footnotetext{
${ }^{1}$ The Dubowitz Neuromuscular Centre, Molecular Neurosciences Section, Developmental Neurosciences Programme, UCL Great Ormond Street Institute of Child Health, London WC1N 1EH, UK. ${ }^{2}$ U955-IMRB, Team 10, Biology of the Neuromuscular System, Inserm, UPEC, ENVA, EFS, Créteil 94000, France.

${ }^{3}$ NIHR Biomedical Research Centre, University College London, Great Ormond Street Institute of Child Health and Great Ormond Street Hospital NHS Trust, 30 Guilford Street, London WC1N 1EH, UK. ${ }^{4}$ Inter-University Laboratory of Human Movement Biology (LIBM)-EA7424, Université Savoie Mont Blanc, Campus Scientifique Technolac, 73376 Le Bourget du Lac Cedex, France. ${ }^{5}$ Nord/Est/lle-de-France Reference Centre for Neuromuscular Diseases, Henri Mondor University Hospital (APHP), 94000 Créteil, France. Correspondence and requests for materials should be addressed to

J.E.M. (email: jennifer.morgan@ucl.ac.uk) or to M.B. (email: m.bencze@ucl.ac.uk)
} 